\title{
СУЧАСНИЙ СТАН РИНКУ ЖИТЛА В УКРАЇНІ
}

\section{THE CURRENT STATE OF THE HOUSING MARKET IN UKRAINE}

\author{
Тригуб Р. М. к.т.н., доцент, Бондаренко О. Ю. студент, \\ Довбуш В. А., студентка (Національний технічний \\ університет «Київський національний університет будівництва i \\ архітектури», м. Київ)
}

Trigub R.M. PhD., associate professor, Bondarenko O.Y., postgraduate student, Dovbush V.A., postgraduate student (National Technical University "Kyiv National University of Construction and Architecture", Kyiv)

Одним із важливих об'єктів інвестування в украӥнців є будівельна галузь, а саме ринок нерухомості. Його перспективи дуже актуальні. На сьогодні иіна йде вгору, а все тому, щчо насамперед в Украӥні зростає багато різних адміністративних перешкод для забудовників. I тому потенційне зростання рентабельності забудовників занепадає. Не покрашується стан фондів, тому украӥнці не мають змоги будувати більше. До того ж збільшується вартість будівельних матеріалів, але зарплатня працівникам на будівництві не зростає. $A$ збільшення ціни на газ $і$ взагалі енергоносїв є суттєвою частиною собівартості будівельних матеріалів. Ріст тарифів на електроенергію змушує людей шукати економніші й вигідніші варіанти обслуговування власних потреб. Все більше стає прихильників альтернативної енергетики - вітряної, теплової чи сонячної. Тому набуває актуальності «зелене» будівництво. На жаль, у наш час попит диктує пропозицію, $і$ як відомо, зниження вартості житла експерти у сфері нерухомості не прогнозують.

Real estate has always been, is and will be the center of research in any country. After all, the real estate market is connected with all spheres and branches of the economic system. As a result, it is very important to identify trends in further development in real estate and construction, to determine the level of its operation and the factors influencing its work. It is known, one of the main objects of investment among Ukrainians is the construction industry, namely the real estate market, whose prospects are very important and relevant. Today, the price is going up, and all because, first of all, in Ukraine there are many different administrative barriers for developers. And so the potential increase in profitability of developers is dying. The condition of the funds is not improving, so we are not able to build more. In addition, the cost of construction materials increases and the salaries of construction workers decrease. And the increase in the price of gas and energy in general is a significant part of the cost of building materials. Rising electricity tariffs are forcing people to look for more economical and profitable options for serving their own needs. There are more and more supporters of 
alternative energy - wind, heat or solar. Therefore, "green" construction becomes relevant. Unfortunately, nowadays demand dictates supply, and as you know, real estate experts do not predict a decrease in the cost of housing. Thus, the volume of housing construction has increased in value. But the need to provide housing for ordinary citizens remains relevant in all regions. For buyers with higher purchasing power, the advantages of choosing housing are the creation of additional comfort conditions. Ordinary citizens can buy real estate only by selling their previous property.

Ключові слова: нерухомість, будівельна галузь, фонд, квадратний метр, ціна, енергоносіі, електроенергія, сонячні панелі, теплова енергія, вітрова електроенергія, «зелене» будівництво

Keywords: real estate, construction industry, fund, square meter, price, energy, electricity, solar panels, thermal energy, wind electricity, "green" construction.

Постановка проблеми. У даний час формування ринку нерухомості потребує поглиблених досліджень для визначення тенденцій подальшого розвитку, визначення рівня його функціонування та факторів, що впливають на його роботу. Бо ринок нерухомості зав'язав стосунки з усіма сферами й галузями загальної економічної системи будь-якої країни.

Будівельна галузь створює об'єкти ринку нерухомості, формуючи їх будівлі, споруди, масштаби. Для цього ринок капіталу повинен мати будівлі та споруди, необхідні для функціонування організації (фінансові, логістичні компанії, банківські установи).

Як відомо, ринок нерухомості України має чотири основні напрями діяльності:

- інвестиції в нерухомість;

- сприяти розвитку інших відповідних галузей економіки, пов'язаних із будівництвом; людей;

- ринок послуг, що створює необхідні умови для існування та життя

- загальний ринок нерухомості, де об'єктами нерухомості є особливі товари.

Аналіз останніх досліджень і публікацій. Аналіз досліджень показує, що за даними статистики, в Україні на одного мешканця розраховується 24 квадратних метрів житлової площі, 3 яких 75\% старий фонд, а чверть житла підпадає аварійному стану, а третя частина житла є новою або реставрованою [1]. Кожного року Україна будує майже 10 мільйонів квадратних метрів житла, а це 0,25 метра на людину в рік. По підсумках, лише $30 \%$ фондів у придатному стані, то їх загальний обсяг не перевищує триста мільйонів метрів, а це сім метрів на особу [1].

Виділення невирішених раніше частин загальної проблеми. Сектор нового житла в Україні не може бути джерелом падіння цін, адже протягом десяти років країні необхідно мати нормальні обсяги будівництва та достатню кількість нових коштів. Ось чому в 
довгостроковій перспективі новий внутрішній ринок є більш вразливим до дефіциту пропозицій.

Що стосується старих фондів, то у населених пунктах зі стрімким скороченням населення старі кошти часто залишаються надлишковими, а нові будинки не будуються. Але для них ціна відповідно відображає поточну ситуацію, адже ціна квартири там менше 10 тисяч доларів. Більшість житла, яке руйнується не має перспектив у майбутньому. Тому ціна такої нерухомості буде становити нуль. До речі, у місті Київ на одного мешканця припадає двадцять метрів старих і нових будинків, а це уже нижче середнього в країні.

Метою статті є аналіз ринку нерухомості і ціни на неї в Україні, які зараз залежать від багатьох факторів, але насамперед від величини попиту. Якщо країна та жителі стають багатшими, то і ціни на нерухомість зростають і навпаки.

Постановкою завдання $\epsilon$ дослідити, які фактори вливають на дорожчання нерухомості в Україні та на що чекати далі від ринку нерухомості.

Виклад основного матеріалу. Сучасний стан ринку житла в Україні. Якби в Україні було б більшість фондів у прийнятному стані i будували б значно більше, то, скоріш за все, українці мали б змогу купити один квадратний метр за місячну зарплатню. Але у теперішній час імпонують високі відносини з цінами, тому що існує недолік пропозиції.

Зі зростанням ціни має зростати і рентабельність будівництва, відповідно збільшилися б обсяги будівництва. Але, на жаль, в Україні вирують адміністративні перешкоди для забудовників, тому запити ринку ростуть, а будівельники не мають змоги обслуговувати їх. Відповідно разом зі зростанням зарплат і цін на будівельні матеріали у будівельників збільшуються витрати, а влада все далі проявляє ініціативу через податки, саме тому потенційне зростання рентабельності забудовників підпадає краху. Як наслідок, після зростання цін на нерухомість обсяги будівництва лише впадуть.

«Уже 3 початку 2021 року ціни на житло в країні виросли в середньому на 20\%. Однак і це $є$ не межа, бо президент Конфедерації будівельників України Лев Парцхаладзе повідомив, що через пандемію ціни на житло мали б знизитись. Подекуди за рік вартість помешкань збільшилась на $10-30 \% »$ [2].

Експерти зазначають, що $є$ кілька причин для здорожчання квартир, зокрема:

- зросла вартість будівельних матеріалів;

- працівникам на будівництві доводиться платити більше.

«Попит диктує пропозицію - ця закономірність $є$ ще однією причиною, чому зросла вартість нерухомості. Адже у неї найчастіше вкладають гроші українці, тому що банки значно знизили відсоткові 
ставки депозитів. У $2019-2020$-х роках банки пропонували кредити під $18-20 \%$ річних. Але у 2021 році деякі банки готові видати кредити навіть до $10 \%$ » [2].

«Дорожчою буде нерухомість, якщо депутати проголосують за законопроєкт № 5600, який запроваджує необхідність сплати компаніями ПДВ при проведенні операцій з нерухомістю на вторинному ринку» [2]. Громадян, які продають понад два «об'єкти нерухомості на рік, зобов'язуватимуть сплачувати $18 \%$ ПДФО з кожної наступної угоди. Зараз у ціні квартир податок на додану вартість уже врахований. Ці 20\% забудовник закладає, коли вперше продає новозбудоване житло» [2].

Ще причиною зростання цін на квартири може стати ціна на газ. Адже вартість газу і взагалі енергоносіїв є суттєвою частиною собівартості будівельних матеріалів. Тому свої витрати забудовники будуть додавати до вартості квартир на первинному ринку.

Через захмарні ціни на світових ринках Україна практично зупинила імпорт газу. Сховища практично не наповнюються газом для його використання протягом осінньо-зимового періоду. Наприклад, за 26 днів вересня було закачано лише 642 млн. м. куб. газу, а це втричі менше, ніж у минулому році [3].

У разі, якщо найближча зима буде холодною, якщо ціна газу у світі збережеться на високому рівні, а наш північний сусід чинитиме провокації на точках входу в українську газотранспортну систему, то у лютому Україна зіштовхнеться 3 дефіцитом газу, який просто фізично неможливо буде покрити 3 жодного напряму. Тут наслідки можуть бути набагато небезпечніші, ніж наслідки віялових відключень електроенергії.

Що стосується електроенергії, то станом на ранок 29 вересня поточного року на складах теплових електростанцій було накопичено 874 тис тонн вугілля, що у порівнянні з обсягом на таку ж дату минулого року складає лише $30,1 \%$ [4].

Рівень накопичення вугілля демонструє, наскільки країна готова до проходження осінньо-зимових піків споживання електричної енергії. Адже здебільшого саме блоки теплової генерації, які здатні кілька разів на добу змінювати навантаження, відповідають в енергосистемі за балансування тижневих і добових графіків виробництва та споживання електроенергії.

Якщо не буде достатньо вугілля на тепловій електростанції через нестачу його накопичень, то відповідні енергоблоки не виконають команду диспетчера "Укренерго" і не зможуть запуститися. Тому частота у мережі буде падати і для уникнення масштабних аварій в системі за командою диспетчера будуть задіяні графіки аварійного відключення споживачів.

У кожному регіоні країни є такий графік, погоджений керівником місцевої державної адміністрації, у якому значні споживачі розділені на кілька черг, відповідно до яких їх будуть відключати за командою 
диспетчера. Врешті бізнесу потрібен час, щоб внести можливі зміни до робочих графіків, технологічних схем, провести закупівлі необхідного резервного генеруючого обладнання. Але, здається, про споживача знову забули.

До того ж зараз будівельна галузь відчуває нестачу будівельних матеріалів. Дефіцит у сукупності 3 ростом витрат на виробництво неминуче спричинять збільшення вартості будівельних матеріалів. Ну, а оскільки попит на нерухомість зараз непоганий, то й забудовники будуть намагатися собі ні в чому не відмовляти, закладаючи в ціни на житло не тільки збільшену собівартість будматеріалів, а й свої побажання по надприбутках.

Ріст тарифів на електроенергію - змушують людей шукати економніші й вигідніші варіанти обслуговування власних потреб. Все більше стає прихильників альтернативної енергетики - вітряної, теплової чи сонячної. Сонячні батареї черпають електрику від світлової енергії сонця.

Сонячні панелі - це лише частина сонячної електростанції. Самі по собі вони не несуть ніякої користі, а от в сукупності з інвертором та комплектуючими - це вже робоча станція. Станція приносить користь через два моменти - економія на виплатах за електроенергію та заробіток по «зеленому» тарифу. Дорого лише на старті, потім інвестиції в сонячну станцію повертаються (від 4 до 8 років), а в подальшому приносять дохід. Монтаж станції можуть зробити кваліфіковані спеціалісти, які добре знають свою роботу. Терміни виконання замовлення різні залежно від складності та потужності. Для прикладу, у середньому одна монтажна бригада може змонтувати дахову СЕС на 10 кВт за 5-7 робочих днів, а наземну на 30 кВт (з саморобною конструкцію з чорного металу) - за 12 робочих днів. Тому, обслуговування станція не потребує взагалі, лише моніторинг та нагляд [5].

Екологічно чиста енергія вітру, яка вважається невичерпною, - це енергія вітру. Це одне з вдалих і економічних рішень для встановлення вітрових турбін у віддалених районах. Вартість такої установки потужністю 1 МВт на сьогодні буде 1 мільйон доларів. Але нестабільність полягає в неможливості гарантувати потрібну кількість електроенергії на певних ділянках землі [6].

Енергія, що накопичується в повітрі, придатна для обігріву приміщення та приготування гарячої води. Тепловий насос використовує це і знижує витрати на вироблення тепла. Однак деякі типи теплових насосів також відрізняються за дозволами, вимогами до будівництва та системою опалення. Слід зазначити, що ціни та експлуатаційні витрати на різні типи тепло-насосного обладнання сильно відрізняються. I, звичайно, це не дешеве задоволення. У висновку спаду вартості житла експерти у сфері нерухомості не прогнозують. Навпаки, ціна і надалі буде зростати, 
так як зростають ціни на енергоресурси, будівельні матеріали та роботу. Кілька відсотків квартири додадуть у вартості вже до кінця 2021 року.

Висновки. Отже, варто зазначити, що збільшився обсяг житлового будівництва, проте потреба у забезпеченні житлом пересічних громадян все ще існує у всіх регіонах. У середньостроковій перспективі через зростання інженерних, енергетичних та матеріальних витрат конкуренція за землю серед забудовників загострилася, тому очікується зниження рентабельності будівництва житла. Маємо зазначити, що інвестиції, необхідні для завершення існуючих проєктів та реалізації нових, є серйозно недостатніми. Фінансова спроможність українських будівельних компаній відносно невелика $\mathrm{i}$ не спроможна забезпечити повне будівництво житлових і нежитлових будинків, бо процес вимагає багато вкладень і часу. Властивим для сучасного ринку нерухомості є те, що забудовники змінюються до потреб споживачів. У державному секторі це - зменшення загальної площі будинків, що сприяє зростанню попиту на первинному ринку житла. Вартість такого житла знижена до межі цін на вторинного ринку. Для покупців 3 вищою купівельною спроможністю перевагою вибору житла $\epsilon$ створення комфортних умов. Інновації, спрямовані на енергозбереження, також позитивно вплинули на стан ринку нерухомості. У сучасну епоху важливим є як придбання житла, так i подальша оплата комунальних послуг. Тому «зелене» будівництво стає все більш актуальним і вітчизняні забудовники переходять до платформи екологічного стандарту, бо $з$ екологічної точки зору експлуатація «зелених» будівель $\epsilon$ вигідною ніж традиційна забудова.

Негативними факторами, що вливають на формування ринку нерухомості, є чисельність населення, зниження їх доходів, нестабільність курсу гривні, складна політична та економічна ситуація в країні. Саме тому звичайні громадяни можуть купити нове майно лише тоді, коли продадуть старе.

\section{References}

1. Chy ye bulbashka na rynku nerukhomosti Ukrainy. Mynfyn - vsë o fynansakh: novosty, kursu valiut, banky. [Digital sourse]. Access: https://minfin.com.ua/ua/realty/articles/est-li-puzyr-na-rynke-nedvizhimosti-ukrainy/ (data zvernennia: 23.10.2021).

2. DailyLviv.com. Zhytlo dorozhchaie: prychyny zbilshennia tsiny nerukhomist. Novyny Lviv - DailyLviv.com. [Digital sourse]. Access https://dailylviv.com/news/ekonomika/zhytlo-dorozhchaie-prychyny-zbilshennya-tsinynerukhomosti-92982 (data zvernennia: 23.10.2021).

3. Tsiny na zhytlo zminiatsia cherez zrostannia taryfiv na haz: pervynnyi rynok chekaie cherhove podorozhchannia. Today.ua. [Digital sourse]. Access: 
https://biz.today.ua/russkyj-tseny-na-zhyle-yzmenyatsya-yz-za-rosta-tseny-na-gazpervychnyj-rynok-zhdet-ocherednoe-podorozhanye/ (data zvernennia: 23.10.2021).

4. Ekonomichna pravda. Na Ukrainu nasuvaietsia idealnyi enerhetychnyi shtorm. Ekonomichna pravda. [Digital sourse]. Access: https://www.epravda.com.ua/columns/2021/10/1/678339/ (data zvernennia: 23.10.2021).

5. Soniachna enerhetyka ta mify pro nei - spetsializovani enerhetychni tekhnolohii. Spetsializovani Enerhetychni Tekhnolohii [Digital sourse]. Access: https://setech.in.ua/sonjachna-energetika-ta-mifi-pro-nei/ (data zvernennia: 23.10.2021).

6. Perevahy ta nedoliky vitrovoi enerhetyky. Ekolohiia zhyttia. [Digital sourse]. Access: https://eco-live.com.ua/content/blogs/perevagi-ta-nedol-ki-v-trovo-energetiki (data zvernennia: 23.10.2021).

\section{Список використаної літератури}

1. Чи є бульбашка на ринку нерухомості України. Мінфин - всё о финансах: новости, курсы валют, банки. [Електронний ресурс]. Режим доступу: https://minfin.com.ua/ua/realty/articles/est-li-puzyr-na-rynke-nedvizhimosti-ukrainy/ (дата звернення: 23.10.2021).

2. DailyLviv.com. Житло дорожчає: причини збільшення ціни нерухомість. Новини Львів - DailyLviv.com. [Електронний ресурс]. Режим доступу: https://dailylviv.com/news/ekonomika/zhytlo-dorozhchaie-prychyny-zbilshennya-tsinynerukhomosti-92982 (дата звернення: 23.10.2021).

3. Ціни на житло зміняться через зростання тарифів на газ: первинний ринок чекає чергове подорожчання. Today.ua. [Електронний ресурс]. Режим доступу: https://biz.today.ua/russkyj-tseny-na-zhyle-yzmenyatsya-yz-za-rosta-tseny-na-gazpervychnyj-rynok-zhdet-ocherednoe-podorozhanye/ (дата звернення: 23.10.2021).

4. Економічна правда. На Україну насувається ідеальний енергетичний шторм. Економічна правда. [Електронний ресурс]. Режим доступу: https://www.epravda.com.ua/columns/2021/10/1/678339/ (дата звернення: 23.10.2021).

5. Сонячна енергетика та міфи про неї - спеціалізовані енергетичні технології. Спеціалізовані Енергетичні Технології [Електронний ресурс]. Режим доступу: https://setech.in.ua/sonjachna-energetika-ta-mifi-pro-nei (дата звернення: 23.10.2021).

6. Переваги та недоліки вітрової енергетики. Екологія життя. [Електронний pecypc]. Режим доступу: https://eco-live.com.ua/content/blogs/perevagi-ta-nedol-ki-vtrovo-energetiki (дата звернення: 23.10.2021). 